\title{
Research on Innovative Modern Apprenticeship System in Vocational Colleges---Illustrated by the Example of Cartoon Creation
}

\author{
Baochun Zhao ${ }^{1,}$, Keliang Zhang ${ }^{2, b}$ and Minhong Dai ${ }^{1, c^{*}}$ \\ ${ }^{1}$ Hainan College of Software Technology, Qionghai, Hainan, China \\ a365830833@qq.com, c277433225@qq.com \\ *The corresponding author
}

\begin{abstract}
Keywords: Integration of production and education; Innovative apprenticeship; Positive teaching mechanism; Echelon personnel training; Modern Apprenticeship
\end{abstract}

\begin{abstract}
Key Tasks of the Ministry of Education in 2014" planned to comprehensively promote the modern apprenticeship pilot clearly. Modern apprenticeship, as the name implies, is based on the traditional apprenticeship reform and innovation, which is a "school-enterprise cooperative vocational education system" through the combination of traditional apprenticeship training and modern school education. The implementation of modern apprenticeship has become an important trend in the reform and development of higher vocational education, which has also been recognized by most vocational education workers and practiced in many vocational colleges. This paper takes cartoon professional development in Hainan College of Software Technology as an example to innovate modern apprenticeship and realize a "new modern apprenticeship", including three-level tutor responsibility system that master leads, tutor is responsible for and teacher guides. It should achieve project teaching contents, work teaching methods, workplace teaching environment, product teaching results, process management course and enterprise organization management in the process of teaching reform, thus greatly improving teaching and research and establishing a positive teaching mechanism. Also the echelon personnel training mode in innovative modern apprenticeship can maximize the integration of production and education, and make vocational institutions development reach a new height.
\end{abstract}

\section{Introduction}

In order to realize the development of high quality talents training in vocational education, we should study the implementation of "modern apprenticeship" in Vocational colleges. Through the analysis of the problems existing in the development of modern apprenticeship in vocational colleges, it is found that only by summarizing the experience can we make the vocational colleges to cultivate talents with high quality. In this paper, the reform and innovation of the modern apprenticeship system in vocational colleges have been studied, and a new type of apprenticeship system has been developed. The "three level tutorial system" is divided into the following three grades. The modern apprenticeship system has been upgraded to "innovative modern apprenticeship system", which can meet the needs of vocational schools in our country, and realize the goal of developing vocational education and talent cultivation.

\section{The Problems of Traditional Apprenticeship}

Preliminary Phase. The development of the modern apprenticeship in China is still in the exploratory stage and lacks cultural atmosphere, especially that the corporate social responsibility and participation are not strong, the enterprises have no obligations and responsibilities to participate in the vocational education and unreleased related government subsidies. Therefore, China's modern apprenticeship mainly depends on colleges and universities that actively look for enterprises for cooperation, while most companies take a wait-and-see attitude and lack enthusiasm and motivation. 
Teachers Quality. Teachers, one of the main subjects in modern apprenticeship, do not play an important role in the apprenticeship implementation, not participate in the project production and the improvement of students' comprehensive quality and not reflect their value.

Limitations. There is a limitation in teaching and research results that enterprises only focus on the result and interest. After the cartoons production, they are not involved in the transformation of teaching results, so the scientific research can only be the subject that a professor or lecturer studied in the past or the project, book and paper based on the changes in the past subjects, with large limitations and without innovative contents.

\section{The Causes of These Problems at Present}

The enterprises lack enough understanding for apprenticeship and often treat students as cheap labor force. After a training, they are not willing to conduct a higher-level training for students and increase training costs.

Vocational school teachers work only for titles and salaries. In addition to routine teaching, most teachers either prepare materials for the title or start a business to handle other things during the remaining time, unable to complete their own work. and lacking overall consciousness in vocational education development.

\section{Innovative Modern Apprenticeship---"Three-Level Tutor Apprenticeship"}

What Is Innovative Modern Apprenticeship. Innovative modern apprenticeship is a mode of education promoted by industry experts, business executives and school teachers to form a set of cartoon production system led by industry experts (masters), guided by business executives (tutors) and monitored by school teachers (teachers).Its educational objects are students, which aims to have practical learning from the perspective of students and work from the social point of view. For them, schooling is employment, bringing business projects to the classroom and becoming the teaching cases. Therefore, students and employees can receive the appropriate wages from the enterprise. This model conducts a unique innovation based on the modern apprenticeship, dividing teachers into three levels, master, tutor, and teacher and forming "three-level tutor apprenticeship."

\section{The Problems that Innovative Modern Apprenticeship Solves}

Industry Development. The traditional apprenticeship only emphasizes on the skills transferring and relies on the experience; while the innovative modern apprenticeship adds the industry masters and the advanced concepts of the industry development needs in the cartoon creation process.

Innovation Ability. In the traditional apprenticeship, apprentice learns totally in accordance with the imparted knowledge of the teacher; while the innovative modern apprenticeship focuses on training students innovation in the cartoon production process and teaching them how to infer other things from one fact.

Business Cases. The innovative modern apprenticeship brings the business cases directly to the classroom and the class is the project production process, which really realizes school-enterprise cooperation. After graduation, students can work directly to win a good reputation for the school, thus solving the difficult enrollment.

\section{Advantages of Innovative Modern Apprenticeship}

Innovative modern apprenticeship is the mode of education of "three-level tutor apprenticeship" with the master, tutor and teacher that connects industry experts with business executives and school teachers through a certain way, taking the industry development and business positions as the basic support, business executives and school teachers as the mentor and the improvement of students professional skills and qualities as the purpose. Combining the relevant practice and research in recent years, the innovative modern apprenticeship has the following advantages. 
Optimize the Organization Management in the Teaching Process. Modern apprenticeship makes the students practice in the enterprise and some cases teaching in the class, which is not conducive to the entire teaching process management and generating the fragmented, interrupted in teaching process easily. Innovative modern apprenticeship is to integrate business projects into the teaching process under the overall control of the master, the guidance of the tutor and the quality supervision of the teacher, thus optimizing the multi-change of teaching organization and management.

Reduce the Running Cost of Vocational Education. The industry leading and enterprise support are the important strength in innovative modern apprenticeship education model, which play the fundamental role. In the absence of industry leading and enterprise support, the schools can move steadily, blindly construct training venues and purchase training equipment, which undoubtedly increase the running costs of the schools. While the participation of industry experts and enterprises has realized the integration and sharing of school educational resources and social resources. In short, "innovative modern apprenticeship" reduces the vocational education costs and realizes the "win-win" of school-enterprise cooperation.

\section{Achievements and Social Effects of Innovative Modern Apprenticeship}

Innovative modern apprenticeship enriches the scientific research breakthroughs of vocational school teachers in various fields, in the cartoon project production process, teachers, as the main body, transfer the final products into scientific research achievements under the guidance of industry experts and experience summary of business executives, which are not only in teaching, but also in students enterprise management and project production.

The participation of industry masters can strengthen the school's teaching staff, also the teacher teams structure is more comprehensive.

The school's visibility is significantly improved, undertaking commercial projects of international, CCTV and well-known enterprises and making schools appear in the international, China Central Television and the major media.

Under the leadership of industry masters, to research the local characteristics of culture, pave the way for the local original project creation and cooperate with local enterprises to create commercial projects serving for local economy.

\section{Conclusion}

The construction of innovative modern apprenticeship talent cultivation mode is the important measure of modern vocational education adapting to the new normal development and coping with the economic and social development that can promote the in-depth development of China's vocational education and teaching reform, push forward innovative modern apprenticeship effectively and make the "three-level" of master, tutor and teacher, which is conducive to the integration of education main bodies, including dual identity of students and apprentice and to enhancing the knowledge abilities of education objects, and the simulation of the business environment can make students adapt to the future work environment as soon as possible. The continuous improvement of innovative modern apprenticeship will surely promote the healthy development of modern vocational education, promote the cultivation of modern advanced technical talents and meet the needs of industry and enterprises for high-level skilled talents, thus promoting the economic and social development, achieving the transformation of Chinese manufacturing to Chinese creation and promoting the realization of the great Chinese dream.

\section{References}

[1] Shiming Zhu. The Advantage and Way of Personnel Training under the Background of Modern Apprenticeship, Chinese University Technology Transfer, 2016(10)

[2] Li Qingqing. Research on the strategy of external environment protection of modern 
apprenticeship system in higher vocational colleges, educational economy and management, 2013, pp.11-15.

[3] Weiguo Zhang. An Overview of the Status of Teachers' Professional Ethics Construction in Higher Vocational Colleges, Education Time, 2016(13)

[4] Xia Wu. Advantages and Difficulties of Modern Apprenticeship Education, Human Resource Management and Cultivation of Talents, 2015(12)

[5] Zhao Yousheng. The practice of modern apprenticeship in vocational education, higher education press, 2015, PP. 38-62.

[6] Sun Yuzhi. Modern apprenticeship in Europe. China Labor and social security press, 2016, PP.20-22.

[7] Liu Yun. Research Report on the cultivation and growth of innovative talents, Science Press, 2013, pp.159-187.

[8] Song Yu. Problems and Countermeasures of Vocational Colleges and Universities Implementing the Modern Apprenticeship, Personnel Training and Vocational Education Communication, 2015(35)

[9] Huang Yao. The situation of Vocational Education in China and the future development of China's Vocational and technical education, 2008 (23)

[10] Yu Li. A brief discussion on the construction of characteristic campus culture under the cooperation of school and enterprise, Proceedings of the Symposium on modern education and teaching exploration in March 2016, 2016 (3) 